J. Lake Sci.(湖泊科学), 2009, 21(6): 855-864 http://www.jlakes.org. E-mail: jlakes@niglas.ac.cn (C)2009 by Journal of Lake Sciences

\title{
新疆乌伦古湖浮游植物群落结构"
}

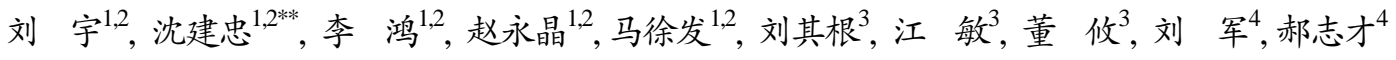

(1: 华中农业大学水产学院, 武汉 430070)

(2: 农业部淡水生物多样性保护和利用重点开放实验室, 武汉 430070)

(3: 上海海洋大学生命科学学院, 上海 200090)

(4: 新疆福海水产局, 福海 836400)

摘 要: 于2006年11月至2007年7月按季度对乌伦古湖浮游植物进行了取样调查, 共发现浮游藻类164种(包括若干未定名种), 隶属于8门90属, 其中Anabaena bergii为新疆新记录种, 两种硅藻Chaetoceros sp. 和Thalassionema sp. 属于海产种类. 各季种类 组成均以绿藻门和硅藻门为主, 蓝藻门和裸藻门次之, 甲藻门、金藻门、黄藻门、隐澡门种类均比较少. 秋季种类最多, 有 141 种; 其次是夏季和春季, 分别为 128 种和 121 种; 冬季种类最少, 仅有95种. 中华小尖头藻、微小四角藻、小形月牙藻、小球藻 及尖针杆藻为全年可见优势种; 肘状针杆藻在春季、夏季和秋季构成优势种群; 扭曲蹄形萂和椭圆小球藻仅在夏季构成优势 种群, 而水溪绿球藻和粗刺四棘藻仅在冬季构成优势种群. 藻类生物量周年变动模式为单峰型, 生物量的峰值出现在夏季 $(6.77 \mathrm{mg} / \mathrm{L})$, 最低值出现在冬季 $(1.45 \mathrm{mg} / \mathrm{L})$. 结合历史资料分析发现, 30年来, 乌伦古湖浮游藻类不仅在种类组成上发生了明 显的变化, 在数量上也显著着一定的增长, 并以绿藻和硅藻类群的增长最为显著.

关键词: 乌伦古湖; 浮游植物; 种类组成; 生物量

\section{Phytoplankton community structure in Lake Ulungur in Xinjiang Uygur Autonomous Region}

LIU Yu ${ }^{1,2}$, SHEN Jianzhong ${ }^{1,2}$, LI Hong ${ }^{1,2}$, ZHAO Yongjing ${ }^{1,2}$, MA Xufa ${ }^{1,2}$, LIU Qigen ${ }^{3}$, JIANG Min ${ }^{3}$, DONG You $^{3}$, LIU Jun ${ }^{4} \&$ HAO Zhicai ${ }^{4}$

(1: The college of Fisheries, Huazhong Agricultural University, Wuhan 430070, P.R.China)

(2: Key Laboratory of Freshwater Biodiversity Conservation and Utilization, Ministry of Agriculture, Wuhan 430070, P.R.China)

(3: College of Aqua-life Science and Technology, Shanghai Ocean University, Shanghai 200090, P.R.China)

(4: Aquatic Bureau of Fuhai of Xinjiang Uygur Autonomous Region, Fuhai 836400, P.R.China)

Abstract: The phytoplankton of Lake Ulungur was investigated seasonally from November, 2006 to July, 2007. A total of 164 phytoplankton species (including a number of unconfirmed species) was detected, which belonged to 90 genera, 8 phylum. Among them, Anabaena bergii was a new record species of cyanophyta in Xinjiang Uygur Autonomous Region, and two species of bacillariophyta, Chaetoceros sp. and Thalassionema sp., belonged to marine algal. In each season, the phytoplankton composition was dominated by Chlorophyta and Bacillariophyta, secondly dominated by Cyanophyta, Euglenophyta, Xanthophyta, Chrysophyta, Cryptophyta and Pyrrophyta. The number of phytoplankton species was the highest in autumn (141 species), followed by the summer (128 species) and spring (121 species), the lowest in winter (95 species). There was an obvious seasonal characteristiscs for the dominant species. Raphidiopsis sinensia, Teraëdron minimum, Selenastrum minutum, Chlorella vulgaris and Synedra acus were dominant

* 新疆福海县政府课题“乌伦古湖渔业资源调查与规划”和国家科技支撑计划“湖泊优质高效增养殖技术研究与示范”课题 (2006BAD03B02)联合资助. 2009-03-13 收稿；2009-05-21 收修改稿. 刘宇, 女, 1983 年生, 硕士研究生; E-mail: liuyuxj@yahoo.com.cn.

** 通讯作者; E-mail: jzhsh@mail.hzau.edu.cn. 
species in the whole year, while Synedra ulna could only be found in spring, summer and autumn. Kirchneriella contorta and Chlorella ellipsoidea dominated in summer, and Chlorococcum infusionum and Treubaria crassispina dominated in winter. The standing crop of phytoplankton peaked only in summer with a biomass of $6.77 \mathrm{mg} / \mathrm{L}$ and the minimum biomass of $1.45 \mathrm{mg} / \mathrm{L}$ occurred in winter. Compared with historical data, the phytoplankton composition had remarkable changes. The growth of green alga and diatom were most notable, while the number of the phytoplankton increased many fold in the past 30 years.

Keywords: Lake Ulungur; phytoplankton; species composition; biomass

乌伦古湖由布伦托海和吉力湖组成, 位于北纬 $46^{\circ} 52^{\prime}-47^{\circ} 28^{\prime}$, 东经 $87^{\circ} 00^{\prime}-87^{\circ} 30^{\prime}$, 地处新疆准葛尔盆 地北部，阿尔泰地区福海县南部．乌伦古河及额尔齐斯河为该湖主要补给水源. 乌伦古湖是乌伦古河的 尾问湖, 水面面积 $917 \mathrm{~km}^{2}$, 湖面海拔高程 $478 \mathrm{~m}$, 咜水量 $77.4 \times 10^{8} \mathrm{~m}^{3}$, 湖水平均水深为 $8 \mathrm{~m}$. 湖区气候寒冷 干燥, 降水稀少, 蒸发强烈 ${ }^{[1-3]}$.

乌伦古湖为新疆维吾尔自治区的第二大湖泊和主要的渔业基地，素以“戈壁大海”和鲜美“福海鱼”而

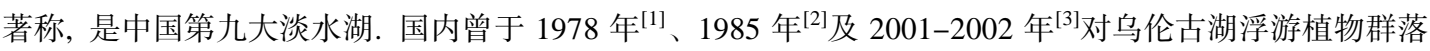
结构做过调查, 但受渔业生产活动、水利工程和气候变化影响, 其水域环境随之发生改变, 水生生物群落 结构及资源状况也会表现出相应的变化, 定期和不定期地对浮游植物等水生生物进行监测和分析, 可以 了解和掌握水域环境和水生生物资源的动态变化, 为保护其环境和合理利用其资源提供科学依据. 本文 通过 2006 年 11 月-2007 年 7 月按季度对乌伦古湖浮游植物的取样调查, 分析了其群落种类组成、优势 种的季节变化, 并通过历史资料的对比, 初步探讨了乌伦古湖浮游植物群落结构的演变以及水利工程和 气候变化的影响, 以期为乌伦古湖水环境的保护及渔业规划提供参考.

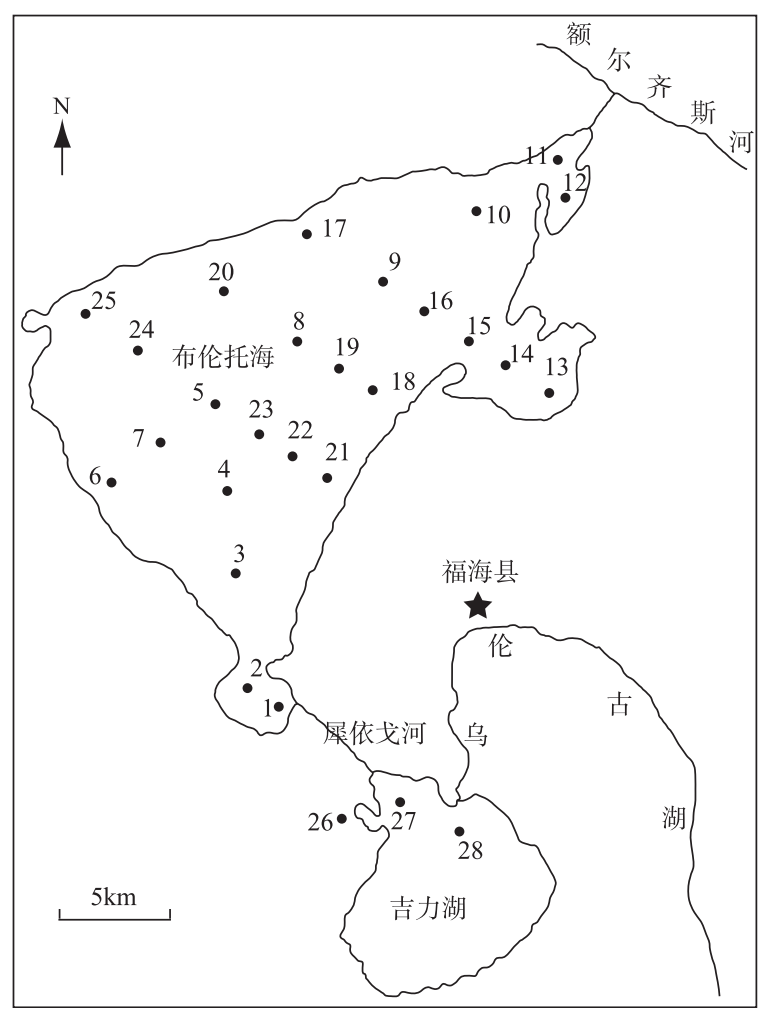

图 1 乌伦古湖采样点分布

Fig.1 The sampling stations in Lake Ulungur

\section{1 研究方法}

\section{1 采样点的设置与采集频次}

1.1.1 采样点的设置 参照《湖泊生态调查观测 与分析》 ${ }^{[4]}$ 并结合乌伦古湖的环境特征，在水 体的中心区、沿岸区及主要进水口共设置 28 个采样点, 其中 $1^{\#}-25^{\#}$ 采样点位于布伦托海, $26^{\#}-28^{\#}$ 位于吉力湖(图 1). 采用 GPS 定位, 确 定采样点位置.

1.1.2 采集频次 2006 年 11 月到 2007 年 7 月, 每季度采样一次, 分别在 2006 年 11 月下旬、 2007 年 1 月下旬、2007 年 4 月下旬和 2007 年 7 月下旬.

\section{2 样本的采集与处理}

根据《湖泊生态调查观测与分析》所述方 法采集并保存浮游植物定性、定量样品 ${ }^{[4]}$. 标 本鉴定参照国内外相关工具书进行 ${ }^{[5-11]}$ ，生物 量的测算采用体积换算法 ${ }^{[4]}$.

\section{3 优势种的确定}

浮游植物优势度 $(Y)$ 的计算公式为:

$$
Y=\left(n_{i} / N\right) f_{i}
$$

式中, $n$ 为第 $i$ 种的个体数, $N$ 为所有种类总个体 数, $f_{i}$ 为出现频率. $Y$ 值大于 0.02 的种类定为优 势种 ${ }^{[12]}$ 


\section{2 结果与分析}

\section{1 浮游植物种类组成及季节变动}

2.1.1 种类组成 根据对 2006 年 10 月-2007年 7 月 4 个季度所采浮游植物所有定性、定量标本的 鉴定结果, 共发现浮游植物 164 种(包括若干未 定名种), 隶属于 8 门 90 属, 其中 Anabaena bergii 为新疆新记录种, 两种硅藻 Chaetoceros sp.和 Thalassionema sp. 属于海产种类(表 1). 绿 藻门(Chlorophyta)有 34 属 69 种, 占浮游植物种 类总数 $42.07 \%$; 硅藻门(Bacillariophyta)有 32 属 53 种, 占 32.32\%; 蓝藻门(Cyanophyta)有 10 属 17 种, 占 $10.37 \%$; 裸藻门(Euglenophyt $a$ ) 有 6 属 13 种, 占 7.93\%; 黄藻门(Xanthophyta)3 属 4 种, 占 2.44\%; 甲藻门(Pyrrophyta)有 3 属 4 种, 占 2.44\%; 金藻门(Chrysophyta) 有 1 属 2 种, 占 $1.22 \%$; 隐藻门(Cryptophyta) 有 1 属 2 种, 占 $1.22 \%$ (图 2). 乌伦古湖浮游植物种类以绿藻门 和硅藻门为主, 占浮游植物种类总数的 $74.39 \%$,

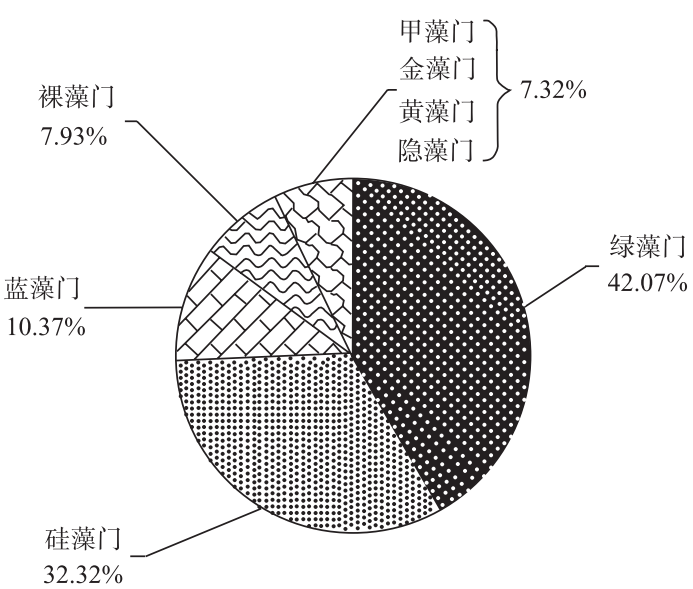

图 2 乌伦古湖浮游植物种类组成

Fig.2 The composition of phytoplankton species in Lake Ulungur 而甲藻门、金藻门、黄藻门、隐藻门种类数都比较少，仅占浮游植物种类总数的 $7.32 \%($ 图 2).

2.1 .2 种类组成季节变动 乌伦古湖浮游植物种类数量上存在明显的季节变化, 秋季种类最多, 有 141 种; 其次是夏季和春季, 分别为 128 种和 121 种; 冬季种类最少, 仅有 95 种. 虽然各季种类组成总体上均呈 现以绿藻门和硅藻门为主, 蓝藻门和裸藻门次之, 甲藻门、金藻门、黄藻门、隐藻门种类较少的基本特 点(表 1), 但各季在种类和种数, 以及优势种种类和种数上依然存在较为明显的变化.

春季, 硅藻种类最多(44 种), 其次是绿藻(43 种), 金藻和隐藻种类最少, 均为 2 种. 在浮游植物群落 中, 中华小尖头藻、微小四角藻、小形月牙藻、小球藻、尖针杆藻及肘状针杆藻数量优势最为明显, 其 次是微囊藻属 sp.、针形纤维藻、镰形纤维藻、盐生顶棘藻及粗刺四棘藻(表 1).

夏季，绿藻种类最多，有 48 种，其次是硅藻，有 41 种，金藻门和隐藻门种类最少，仍为 2 种. 夏季优 势类群中增加了扭曲蹄形藻和椭圆小球藻(图 3), 微囊藻属和针形纤维藻仍具有较高的数量, 此外, 水 华束丝藻、铜绿微囊藻、微小平裂藻、粗壮细鞘丝藻、坑形细鞘丝藻、平片针杆藻、扁鼓藻、水溪绿 球藻的数量均有显著增长. 而水华鱼腥藻、短棘叉星鼓藻、纤细角星鼓藻、光滑鼓藻、多芒藻、单角 盘星藻、布朗盘星藻、被甲栅藻博格变种、卵圆双壁藻和拟丝状黄丝藻均为夏季特有种类, 但数量不 多(表 1).

秋季, 绿藻和硅藻的种类数分别为 54 和 50 , 黄藻种类最少, 仅见 1 种. 秋季优势类群与春季相同, 除 小球藻和肘状针杆藻外, 各优势种的优势度均有明显升高(图 3), 微囊藻属、微小平裂藻、铜绿微囊藻、 针形纤维藻、椭圆小球藻及水溪绿球藻在该季仍保持较高的数量, 盐生顶棘藻、镰形纤维藻、转板藻属、 角毛藻属、脆杆藻属在该季的数量也较多. 而镰形纤维澡奇异变种、四棘藻、纤毛顶棘藻、微芒藻、近 膨胀鼓藻、珍珠角星鼓藻、二角盘星藻大孔变种、丛球韦丝藻、河生集星藻、变异直链藻、颗粒直链藻、 椭圆波缘藻缢缩变种、菱形肋缝藻及篮孔囊裸藻仅在该季出现, 并且数量较少(表 1).

冬季, 绿藻和硅藻仍在群落中占据主导地位, 种类数分别为 39 和 31, 未检到金藻和隐藻种类. 冬季 优势类群由中华小尖头藻、微小四角藻、小形月牙藻、小球藻、尖针杆藻、水溪绿球藻及粗刺四棘藻构 成, 各优势种数量相差较小, 仅见中华小尖头藻占据一定优势(图 3). 针形纤维藻、椭圆小球藻、盐生顶 棘藻及镰形纤维藻仍具有较高的数量, 扭曲蹄形藻和肥壮蹄形藻的数量也明显增加. 而长毛针丝藻仅在 冬季出现, 但数量较少(表 1 ). 
表1 乌伦古湖浮游植物种类及其季节变动 ${ }^{*}$

Tab.1 The phytoplankton species and seasonal variations in Lake Ulungur

\begin{tabular}{|c|c|c|c|c|c|c|c|c|c|}
\hline 种类 & 春季 & 夏季 & 秋季 & 冬季 & 种类 & 春季 & 夏季 & 秋季 & 冬季 \\
\hline 蓝藻门 Cyanophyta & & & & & 针形纤维藻 Ankistrodesmus acicularis & ++ & ++ & ++ & ++ \\
\hline 中华小尖头藻 Raphidiopsis sinensia & +++ & +++ & +++ & +++ & 卷曲纤维藻 Ankistrodesmus convolutus & + & - & - & + \\
\hline 水华束丝澡 Aphanizomeno flos-aquae & + & ++ & + & + & 镰形纤维藻奇异变种 Ankistrodesmus & - & - & + & - \\
\hline 微小平裂藻 Merismopedia tenuissima & + & ++ & ++ & + & falcatus var. mirabilis & & & & \\
\hline 细小平裂藻 Merismopedia minima & + & - & - & + & 湖生卵囊藻 Oocystis lacustris & + & + & + & + \\
\hline 铜绿微囊藻 Microystis aeruginosa & + & ++ & ++ & + & 单生卵囊藻 Oocystis solitaria & + & + & + & + \\
\hline 微囊藻属 Microystis sp. & ++ & ++ & ++ & + & 雉形胶囊藻 Gloeocystis planctonica & + & + & + & + \\
\hline 色球藻属 Chroococcus sp. & + & + & + & + & 双对栅藻 Scenedesmus Bijuga & + & + & + & + \\
\hline 阿氏拟鱼腥藻 Anabaenopsis arnoldii & + & + & + & + & 裂孔栅藻 Scenedesmus perforatus & + & + & + & + \\
\hline 水华鱼腥藻 Anabaena flos-aquae & - & + & - & - & 四尾栅藻 Scenedesmus Quadricauda & + & + & + & + \\
\hline Anabaena bergii ${ }^{1)}$ & - & + & + & - & 尖细栅藻 Scenedesmus Acuminatus & + & + & + & - \\
\hline 粗壮细鞘丝藻 Leptolyngbya valderiana & + & ++ & + & + & 二形栅藻 Scenedesmus Dimorphus & + & + & + & + \\
\hline 厚壁细鞘丝藻 Leptolyngbya lagerheimii & + & + & + & + & 多棘栅藻 Scenedesmus abundans & + & + & + & - \\
\hline 坑形细鞘丝藻 Leptolyngbya foveolara & + & ++ & + & + & 爪哇栅藻 Scenedesmus javaensis & + & + & - & - \\
\hline 浮丝藻属 Planktothrix sp. & + & + & + & + & 龙骨栅藻 Scenedesmus cavinatus & + & + & + & + \\
\hline 阿氏浮丝藻 Planktothrix agardhii & - & + & + & + & 被甲栅藻博格变种双尾变型 & - & + & - & + \\
\hline 小颤藻 Oscillatoria tenuis & - & + & + & - & Scenedesmus armatus var. boglariensis & & & & \\
\hline 大螺旋藻 Spitulina major & - & + & + & - & f. bicaudatus & & & & \\
\hline 绿藻门 Chlorophyta & & & & & 被甲栅藻博格变种 Scenedesmus & - & + & - & - \\
\hline 纺锤藻 Elakatothrix gelatinosa & + & + & + & + & armatus var. boglariensis & & & & \\
\hline 微小四角藻 Teraëdron minimum & +++ & +++ & +++ & +++ & 四角十字藻 Crucigenia quadrata & + & + & + & + \\
\hline 具尾四角藻 Teraëdron caudatum & + & - & + & + & 四足十字藻 Crucigenia tetrapedia & - & + & + & + \\
\hline 膨胀四角藻 Teraëdron tumidulum & + & + & - & + & 河生集星藻 Actinastrum fluviatile & - & - & + & - \\
\hline 二叉四角藻 Teraëdron bifurcarum & + & - & - & + & 短棘盘星藻 Pediastrum biradiatum & + & + & + & + \\
\hline 小形月牙藻 Selenastrum minutum & +++ & +++ & +++ & +++ & 二角盘星藻大孔变种 Pediastrum & - & - & + & - \\
\hline 扭曲蹄形藻 Kirchneriella contorta & ++ & +++ & + & ++ & duplex var. clathratum & & & & \\
\hline 肥壮蹄形藻 Kirchneriella obesa & + & - & - & ++ & 布朗盘星藻 Pediastrum boryanum & - & + & - & - \\
\hline 小球藻 Chlorella vulgaris & +++ & +++ & +++ & +++ & 单角盘星藻 Pediastrum pimplex & - & + & - & - \\
\hline 椭圆小球藻 Chlorella ellipsoidea & + & +++ & ++ & ++ & 平滑四星藻 Tetrastrum glabrum & + & - & + & - \\
\hline 水溪绿球藻 Chlorococcum infusionum & + & ++ & ++ & +++ & 短刺四星藻 Tetrastrum staurogeniaeforme & - & + & + & - \\
\hline 集球藻 Palmellococcus miniatus & + & - & - & + & 华丽四星藻 Tetrastrum elegans & - & + & + & + \\
\hline 长刺顶棘藻 Chodatella longiseta & + & + & + & + & 丛球韦丝藻 Westella botryoides & - & - & + & - \\
\hline 盐生顶棘藻 Chodatella quadtiseta & ++ & + & ++ & ++ & 线形拟韦丝藻 Westellopsis linearis & + & - & + & - \\
\hline 被刺藻 Franceia ovalis & + & + & + & + & 转板藻属 Mougeotia sp. & + & + & ++ & + \\
\hline 纤毛顶棘藻 Chodatella ciliata & - & - & + & - & 小空星藻 Coelastrum microporum & - & + & + & - \\
\hline 四刺顶棘藻 Chodatella quadriseta & + & + & + & + & 棘鞘藻 Echinocoleum elegans & + & - & + & + \\
\hline 粗刺藻 Acanthosphaera zachariasi & + & + & + & - & 微芒藻 Micractiai pusillum & - & - & + & - \\
\hline 粗刺四棘藻 Treubaria crassispina & ++ & + & + & +++ & 多芒藻 Golenkinia radiata & - & + & - & - \\
\hline 四棘藻 Treubaria triappendiculata & - & - & + & - & 拟菱形弓形藻 Schroederia nitzschioides & - & + & + & - \\
\hline 镰形纤维藻 Ankistrodesmus falcatus & ++ & + & ++ & ++ & 螺旋弓形藻 Schroederia spiralis & + & + & + & - \\
\hline
\end{tabular}




\begin{tabular}{|c|c|c|c|c|c|c|c|c|c|}
\hline 种类 & 春季 & 夏季 & 秋季 & 冬季 & 种类 & 春季 & 夏季 & 秋季 & 冬季 \\
\hline 硬弓形藻 Schroederia robusta & + & + & + & - & 头端舟形藻 Navicula capitata & + & + & + & - \\
\hline 扁鼓藻 Cosmarium depressum & + & t+ & + & + & 喙头舟形藻 Navicula cuspidate & + & + & + & + \\
\hline 具角鼓藻 Cosmarium angulosum & - & + & + & - & 瞳孔舟形藻 Navicula pupula & + & + & + & + \\
\hline 项圈鼓藻 Cosmarium moniliforme & - & + & + & - & 瞳孔舟形藻矩形变种 Navicula & + & - & + & + \\
\hline 光滑鼓藻 Cosmarium laeve & - & + & - & - & var. rectangularia & & & & \\
\hline 近膨胀鼓藻 Cosmarium subtumidum & - & - & + & - & 瞳孔舟形澡头端变种 Navicula var. capitata & + & - & + & - \\
\hline 珍珠角星鼓藻 Staurastrum & - & - & + & - & 纤细异极藻 Gomphonema gracile & + & + & + & + \\
\hline margaritaceum & & & & & 长蓖藻属 Neidium sp. & + & + & + & - \\
\hline 纤细角星鼓藻 Staurastrum gracile & - & + & - & - & 具球异菱澡 Anomoeoneis sphaerophora & - & + & + & - \\
\hline 短棘叉星鼓藻 Staurodesmus brevispina & - & + & - & - & 双头辐节藻 Stauroneis anceps & + & + & + & + \\
\hline 具瘤四粒藻 Quadricoccus verrucosus & + & - & + & + & 尖布纹藻 Gyrosigma acuminatum & + & - & + & - \\
\hline 四球藻 Tetrachlorella Korschikoff & + & - & + & - & 施密斯胸膈藻 Mastogloia smithii & + & + & + & + \\
\hline 长毛针丝藻 Raphidonema longiseta & - & - & - & + & 施密斯胸膈藻双头变种 Mastogloia & + & + & + & + \\
\hline 锐新月藻 Closterium acerosum & - & - & + & + & smithii var. amphicephala & & & & \\
\hline 硅藻门 Bacillariophyta & & & & & 美丽双壁藻 Diploneis puella & + & + & + & + \\
\hline 角毛藻属 Chaetoceros sp. ${ }^{2)}$ & + & + & ++ & + & 卵圆双壁藻 Diploneis ovalis & - & + & - & - \\
\hline 梅尼小环藻 Cyclotella meneghiniana & + & + & + & + & 舒曼美壁藻 Caloneis schumanniana & + & - & + & - \\
\hline 广缘小环藻 Cyclotella bodanica & + & + & + & + & 扁形卵形藻 Cocconeis placentula & + & + & + & - \\
\hline 颗粒直链藻极狭变种 Melodira & + & + & + & - & 披针曲壳藻 Achnathes lanceolata & + & + & - & + \\
\hline granulata var. angustissima & & & & & 弯形弯契藻 Rhoicosphenia curvata & + & + & + & + \\
\hline 变异直链藻 Melodira varians & - & - & + & - & 偏肿美壁藻 Caloneis ventricosa & - & + & + & + \\
\hline 颗粒直链藻 Melodira granulata & - & - & + & - & 羽纹澡属 Pinnularia sp. & + & + & + & - \\
\hline 尖针杆藻 Synedra acus & t+t & t+t & t+t & H+t & 菱形藻属 Nitzschia sp. & + & + & + & + \\
\hline 肘状针杆澡 Synedra ulna & t+t & t+t & t+t & t+ & 线形菱形藻 Nitzschia linearis & + & + & + & - \\
\hline 平片针杆藻 Synedra tabulata & + & ++ & ++ & + & 两栖菱形藻 Nitzschia amphibia & - & + & + & + \\
\hline 棱头针杆藻 Synedra capitata & + & - & + & + & 短缝藻属 Eunotia sp. & - & + & - & - \\
\hline 脆杆藻属 Fragilaria sp. & + & + & ++ & + & 粗壮双菱藻华彩变种 Surirella & + & + & + & - \\
\hline 星杆澡 Asterionella formosa & + & - & + & + & robusta var. splendida & & & & \\
\hline 海线藻属 Thalassionema sp. ${ }^{2)}$ & + & - & + & - & 菱形胁缝藻 Frustulia rhomboides & - & - & + & - \\
\hline 窗格平板藻 Tabellaria fenestrata & + & + & + & + & 草鞋形波缘藻 Cymatopleura solea & + & - & + & - \\
\hline 纤细等片藻 Diatoma tenue & + & + & + & + & 椭圆波缘藻缢缩变种 Cymatopleura & - & - & + & - \\
\hline 鼠形窗纹藻 Epithemia argus & + & + & + & + & elliptica var. constricta & & & & \\
\hline 弯棒杆藻 Rhopalodia maxima & + & + & + & + & 甲藻门 Pyrrophyta & & & & \\
\hline 偏肿桥弯藻 Cymbella ventricosa & + & + & + & + & 二角多甲藻 Peridinium bipes & + & + & + & + \\
\hline 膨大桥弯藻 Cymbella turgida & + & + & + & + & 多甲藻属 Peridinium sp. & + & + & + & + \\
\hline 新月形桥弯藻 Cymbella cymbiformis & + & + & + & + & 坎宁顿拟多甲藻 Peridiniopsis & + & + & + & + \\
\hline 细小桥弯藻 Cymbella pusilla & + & + & + & + & cunningtonii & & & & \\
\hline 卵圆双眉藻 Amphora ovalis & + & + & + & + & 角甲藻 Ceratium hirundinella & + & + & + & + \\
\hline 隐头舟形藻 Navicula cryptocephala & + & + & + & - & 裸藻门 Euglenophyta & & & & \\
\hline 嗜盐舟形藻 Navicula halophila & + & + & + & - & 纤细裸藻 Euglena gracilis & + & + & + & + \\
\hline 嗜盐舟形藻 Navicula halophila & + & + & + & - & 多形裸藻 Euglena polymorpha & + & + & + & - \\
\hline 放射舟形澡 Navicula raduiosa & + & + & + & - & 鱼形裸藻 Euglena pisciformis & + & - & + & + \\
\hline
\end{tabular}




\begin{tabular}{|c|c|c|c|c|c|c|c|c|c|}
\hline 种类 & 春季 & 夏季 & 秋季 & 冬季 & 种类 & 春季 & 夏季 & 秋季 & 冬季 \\
\hline 梭形裸藻 Euglena acus & + & + & + & - & 分歧雉囊藻 Dinobryon divergens & + & + & + & - \\
\hline 三棱裸藻 Euglena tripteris & + & + & + & + & 黄藻门 Xanthophyta & & & & \\
\hline 哑铃扁裸藻 Phacus peteloti & + & + & + & + & 葡萄藻 Botryococcus braunii & + & + & + & - \\
\hline 三棱扁裸藻 Phacus Triqueter & - & + & + & - & 小刺角绿藻 Goniochloris & + & + & - & + \\
\hline 圆柱扁裸藻 Phacus cylindrus & + & + & + & + & brevispinosa & & & & \\
\hline 梨形扁裸藻 Phacus Pyrum & + & + & + & + & 小型黄丝藻 Tribonema minus & + & + & - & - \\
\hline 普蒂双鞭藻 Eutreptia pertyi & + & + & + & + & 拟丝状黄丝藻 Tribonema & - & + & - & - \\
\hline 笁孔囊裸藻 Trachelomonas cribrum & - & - & + & - & ulothrichoides & & & & \\
\hline 纺锤鳞孔藻 Lepocinclis fusiformis & + & - & + & - & 隐藻门 Cryptophyta & & & & \\
\hline 秋鳞孔藻 Lepocinclis autumnalis & + & - & + & - & 卵形隐藻 Crytomonas ovata & + & + & + & - \\
\hline 金藻门 Chrysophyta & & & & & 隐藻属 Crytomonas sp. & + & + & + & - \\
\hline 圆筒形雉囊藻 Dinobryon cylindricum & + & + & + & - & 总计 & 121 & 128 & 141 & 95 \\
\hline
\end{tabular}

*-表示未见, +表示存在(相对密度 $\leqslant 5 \%),++$ 表示数量较多 $(5 \%<$ 相对密度 $\leqslant 10 \%),+++$ 表示优势种, 1 )表 示新疆新记录种, 2)表示海产藻类.

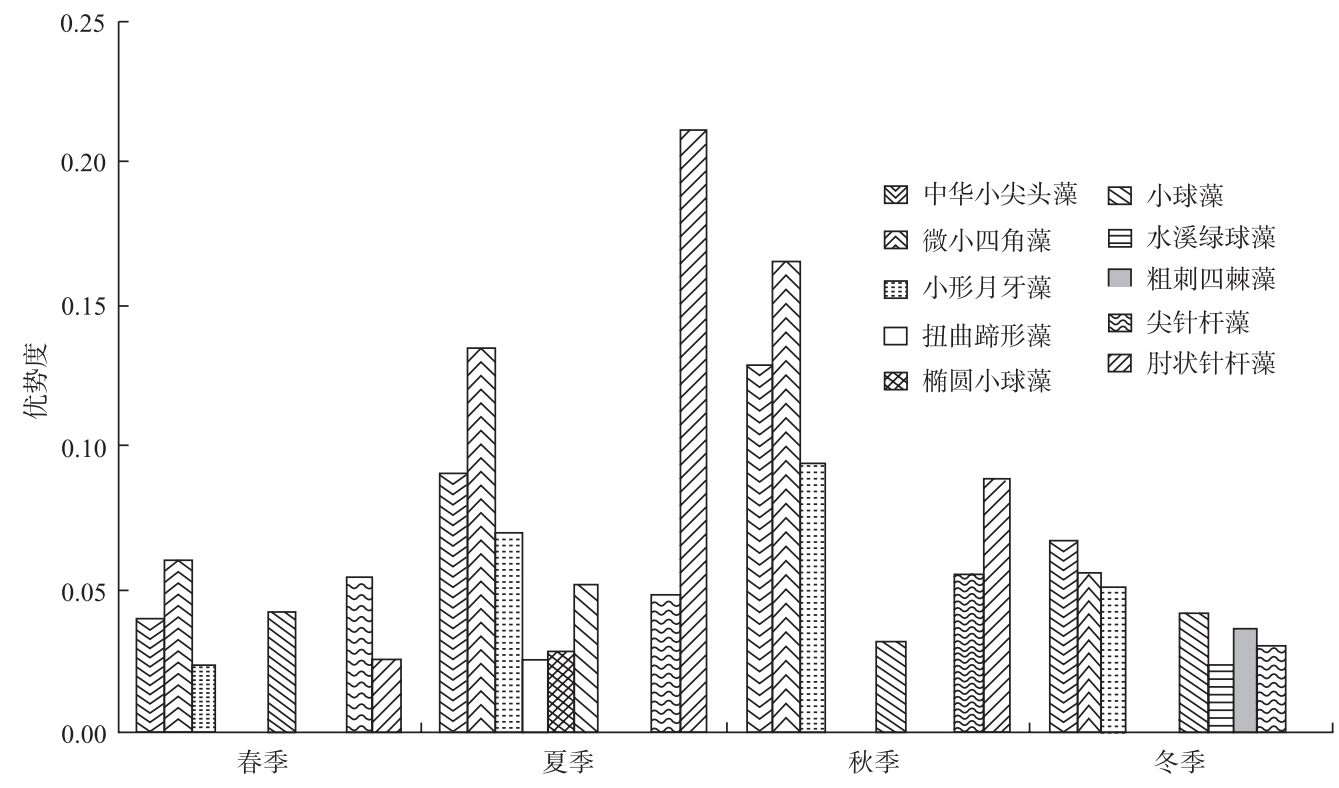

图 3 乌伦古湖优势种的季节变化

Fig.3 The seasonal variations of dominant species in Lake Ulungur

\section{2 生物量的季节变动}

乌伦古湖各季生物量组成均以绿藻、硅藻、甲藻及裸藻为主, 其它各门所占比例均较少(表 2). 春季, 浮 游植物平均生物量为 $2.21 \mathrm{mg} / \mathrm{L}$, 其中硅藻生物量为 $0.75 \mathrm{mg} / \mathrm{L}$, 在群落中占据主导地位, 占春季平均生物量 的 $34.09 \%$, 甲藻位居第二, 占 $25.34 \%$, 绿藻次之, 占 $22.94 \%$; 夏季, 浮游植物平均生物量最高, 为 $6.77 \mathrm{mg} / \mathrm{L}$, 除金藻外, 其它各门生物量均显著增长, 其中绿藻生物量增长最多, 由 $0.51 \mathrm{mg} / \mathrm{L}$ 增加到 $2.61 \mathrm{mg} / \mathrm{L}$, 并取代 了硅藻群落优势, 占该季平均生物量的 $38.52 \%$; 秋季, 浮游植物平均生物量降到 $4.70 \mathrm{mg} / \mathrm{L}$, 除裸藻和金藻 外, 其他各门生物量均有所降低, 其中甲藻生物量降低最多, 较夏季降低了 $0.89 \mathrm{mg} / \mathrm{L}$, 绿藻生物量略有减少, 为 $2.38 \mathrm{mg} / \mathrm{L}$, 仍在群落中占绝对优势, 占该季平均生物量的 $50.61 \%$; 冬季, 浮游植物平均生物量降到最低, 为 $1.45 \mathrm{mg} / \mathrm{L}$, 各门生物量均明显降低, 绿藻生物量降到 $0.58 \mathrm{mg} / \mathrm{L}$, 仍在群落中居首位, 甲藻降到 $0.31 \mathrm{mg} / \mathrm{L}$, 
居第二位, 硅藻生物量由 $1.12 \mathrm{mg} / \mathrm{L}$ 降到 $0.27 \mathrm{mg} / \mathrm{L}$, 降低最多, 位于第三位.

表 2 乌伦古湖浮游植物各季分类生物量 $(\mathrm{mg} / \mathrm{L})$ 及其比例 $(\%)^{*}$

Tab.2 Seasonal variations in biomass and relative biomass of different phytoplankton taxa in Lake Ulungur

\begin{tabular}{|c|c|c|c|c|c|c|c|c|c|}
\hline 节 & 绿藻门 & 圭藻门 & 甲藻门 & 裸藻门 & 蓝藻门 & 隐藻门 & 金藻门 & 黄藻门 & 总计 \\
\hline & $0.51(22.94)$ & $0.75(34.09)$ & (1) & $0.23(10.43)$ & $0.02(1.04)$ & $0.09(3.99)$ & $0.03(1.41)$ & $0.02(1.04)$ & 2.21 \\
\hline 夏季 & & & & & & & & & 6.77 \\
\hline 秋奇 & & & & & & & & & 4.70 \\
\hline 冬季 & 58 (39.82) & $0.27(18.43)$ & $0.31(21.32)$ & $0.20(13.62)$ & $0.09(6.40)$ & $0.00(0.00)$ & $0.00(0.00)$ & $0.01(0.48)$ & 1.45 \\
\hline
\end{tabular}

*括号内为比例.

\section{3 讨论}

\section{1 新疆新纪录种(Anabaena bergii)的时空分布}

在本次调查中发现新疆新纪录种一种(Anabaena bergii), 该种在乌伦古湖的时空分布具有典型的季 节特征和水平特征. 在季节分布上, Anabaena bergii 仅在夏、秋季出现，并且在夏季的生物量明显高于秋 季, 本文认为这种季节分布特征与该藻自身特性有关, Anabaena bergii 隶属于蓝藻门、鱼腥藻属, 适宜在 $25-35^{\circ} \mathrm{C}$ 的温度条件下生长 ${ }^{[11]}$, 乌伦古湖夏季平均水温 $\left(25^{\circ} \mathrm{C}\right)$, 为 Anabaena bergii 提供了良好的生长条件.

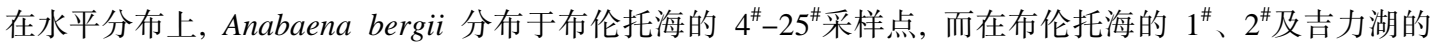
$26^{\#}-28^{\#}$ 却未见该种踪迹, 本文认为这种水平方式可能与乌伦古湖的引水工程和所处地理位置有关. 乌伦 古湖的引水工程有两处, 一处是位于吉力湖东北角的乌伦古河引水工程, 另一处是位于布伦托海东北角 的“引额济海”工程, Anabaena bergii 在吉力湖未见分布, 认为该种很可能由额尔齐斯河引人. 另外, 乌伦 古湖位于北纬 $46^{\circ} 52^{\prime}-47^{\circ} 28^{\prime}$, 东经 $87^{\circ} 00-87^{\circ} 30^{\prime}$, 地处西风区, 湖区气候在西风带模式和季风环流作用下, 常年盛行偏西风 ${ }^{[13]}$, Anabaena bergii 属蓝藻门漂浮性藻类 ${ }^{[14]}$, 很可能受此影响而限制了它在布伦托海的 分布.

\section{2 乌伦古湖盐度历年变化对海产硅藻的影响}

早在1978年, 已发现乌伦古湖存在海产硅藻角毛藻属种类(Chaetoceros sp.), 在乌伦古湖呈区域 性分布. 同年理化资料显示, 吉力湖和布伦托海的水体矿化度分别达到 $426 \mathrm{mg} / \mathrm{L}$ 和 $3430 \mathrm{mg} / \mathrm{L}^{[1]} .2000$ 年 ${ }^{[15]}$ 水化学监测资料表明: 与 1978 年相比, 2000 年布伦托海的矿化度下降到 $2574 \mathrm{mg} / \mathrm{L}$, 但吉力湖的 水体矿化度却有所增加, 上升到 $696 \mathrm{mg} / \mathrm{L}$, 总体来说, 乌伦古湖盐化程度有所减弱, 但仍属弱咸水湖. 而在2001-2002年 ${ }^{[3]}$ 的浮游植物群落结构调查中未见海产硅藻种类的报道，作者认为海产硅藻可能 仍然存在, 只是由于盐度下降, 影响其生长, 导致数量较少而未被采集到. 本次调查发现, 乌伦古湖 的盐度与 1978 年相比有所上升, 布伦托海和吉力湖的水体矿化度分别为 $3520 \mathrm{mg} / \mathrm{L}$ 和 $726 \mathrm{mg} / \mathrm{L}$ (待发 表), 这种盐度的变化导致海产硅藻不但种类增加到2种(Chaetoceros sp.和Thalassionema sp.), 分布区 域也由部分采样点扩散到全湖各采样点. 可见, 乌伦古湖盐度的历年变化对海产硅藻种类的生长及 分布区域都产生了较大的影响. 杨清良等 ${ }^{[16]}$ 在对台湾海峡西侧海域浮游硅藻的调查中也发现, 浮游 硅藻的种类数随盐度的升高有增加的趋势. Kirst ${ }^{[17]}$ 和 Kadiri ${ }^{[18]}$ 在对海藻与盐度关系的研究中发现, 盐度分布的差异决定着藻类分布的区域性. 高亚辉等 ${ }^{[19]}$ 对长江口附近海域, 刘玉等 ${ }^{[20]}$ 对珠江口浮游 藻类研究中也发现, 从近岸到外海, 随盐度的增加, 高盐种类分布呈现递增趋势而低盐种和半咸水 种类呈现递减趋势.

\section{3 乌伦古湖浮游植物群落结构的演变}

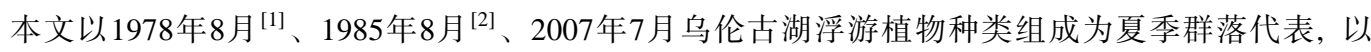
2001-2002年 ${ }^{[3]}$ 、2006-2007年浮游植物种类组成为全年群落代表, 归纳了乌伦古湖浮游植物种类组成及 
各藻门现存量的演变(表3).

表 31978 年, 1985 年, 2001-2002 年和 2006-2007 年乌伦古湖浮游植物种类组成 ${ }^{\text {(** }}$

Tab.3 The phytoplankton composition surveyed in 1978, 1985, 2001-2002 and 2006-2007 in Lake Ulungur

\begin{tabular}{cccccc}
\hline \multirow{2}{*}{ 门类 } & \multicolumn{2}{c}{ 种类数(夏季个体密度, $\left.\times 10^{3} \mathrm{cells} / \mathrm{L}\right)$} & \multicolumn{2}{c}{ 属数(年均生物量, $\mathrm{mg} / \mathrm{L})$} \\
\cline { 2 - 6 } & 1978 年 8 月 & 1985 年 8 月 & 2007 年 7 月 & $2001-2002$ 年 & $2006-2007$ 年 \\
\hline 蓝藻门 & $17(18.67)$ & $3(1.77)$ & $16(191.61)$ & $6(0.37)$ & $10(0.09)$ \\
绿藻门 & $27(--)$ & $11(210.25)$ & $48(385.54)$ & $28(1.99)$ & $34(1.52)$ \\
硅藻门 & $22(35.08)$ & $10(193.41)$ & $41(301.72)$ & $10(0.85)$ & $32(1.02)$ \\
裸藻门 & $4(--)$ & $3(3.01)$ & $9(5.03)$ & $2(0.37)$ & $6(0.39)$ \\
甲藻门 & $3(2.08)$ & $1(21.32)$ & $4(23.42)$ & $2(0.06)$ & $3(0.65)$ \\
金藻门 & - & $1(63.08)$ & $2(1.19)$ & $1(0.03)$ & $1(0.02)$ \\
黄藻门 & $2(--)$ & $2(5.33)$ & $4(6.28)$ & - & $3(0.02)$ \\
隐藻门 & - & - & $2(0.18)$ & $1(0.07)$ & $1(0.08)$ \\
总计 & $6 门 75$ 种 & 7 门 31 种 & 8 门 128 种 & 7 门 50 属 & 8 门 90 属 \\
& $(81.04)$ & $(513.82)$ & $(915.97)$ & $(3.72)$ & $(3.79)$ \\
\hline
\end{tabular}

* - - 表示数据缺失, - 表示未出现.

30年来, 乌伦古湖浮游藻类不仅在种类组成上发生了明显的变化, 在数量上也显著增长(表3). 在夏 季群落结构调查中, 浮游植物种类组成由 1978年8月的6门75种增加到2007年7月的8门128种, 密度由 $81.04 \times 10^{3} \mathrm{cells} / \mathrm{L}$ 增加到 $915.97 \times 10^{3} \mathrm{cells} / \mathrm{L}$, 在周年调查中, 其种类组成由 $2001-2002$ 年的 7 门 50 属增加到 2006-2007年的 $8 门 90$ 属, 年均生物量也由 $3.72 \mathrm{mg} / \mathrm{L}$ 增加到 $3.79 \mathrm{mg} / \mathrm{L}$. 浮游藻类种类数及数量的大幅增长 是水体富营养化程度加强的重要标志, Davis ${ }^{[21]}$ 在总结美国伊利湖44年内浮游植物的年际变化及饶钦止和 章宗涉 ${ }^{[22]}$ 在总结武汉东湖 20 年来的演变时, 均观察到浮游植物随湖泊富营养化水平的加剧种类数增加、 数量大幅增长的现象.

乌伦古湖浮游植物群落组成上的变化具体表现在以下三个方面. 一是小型藻类明显增多, 例如, 绿 藻门小型绿球藻目的种类数大幅上升, 其种类数, 从1978年8月的 $16^{\text {种 }}{ }^{[11}$ 增到 2007 年7月的 41 种, 其属数, 从2002-2004年的20属 ${ }^{[3]}$ 增加到2006-2007年的28属. 二是富营养指示种类显著增加, 主要表现为: 硅藻 门中-富营养和富营养指示种明显增加, 某些种类甚至成为全年可见的优势种(如尖针杆藻). 三是喜清水 种类的个体密度显著下降(金藻)而喜有机质丰富种类的生物量却在上升(隐藻). 有学者认为藻类的小型 化 ${ }^{[23-25]}$ 和富营养指示种类的增长 ${ }^{[26]}$ 是水体富营养化加剧的显著特征，而金藻的减少 ${ }^{[27-29]}$ 和隐藻的增加 ${ }^{[30]}$ 是水体受到有机污染的直接反映.

结合理化指标来看, 1978年8月 ${ }^{[1]}$, 乌伦古湖尚属于贫营养型水体; 而到了 1985 年 8 月 $^{[2]}$, 乌伦古湖已 处于中营养状态; 李新贤等 ${ }^{[31]}$ 指出，乌伦古湖仍属于中营养型湖泊，但水体已受到有机污染; 到 2006-2007年, 董做等 ${ }^{[32]}$ 研究表明, 乌伦古湖总体处于中营养状态, 但在夏季部分湖区(如吉力湖)已达到 中度富营养水平.

乌伦古湖小型种类, 如绿球藻目的增加还可能与鲢、鳙鱼的放养密度有关. 高密度放养的滤食性鲢、 鳙鱼被认为是促进武汉东湖浮游植物小型化的主要原因 ${ }^{[33-34]}$. Jeppesen等 ${ }^{[35]}$ 指出湖泊中高密度放养滤食 性鱼类, 往往会使浮游植物的群落演变成以绿球藻目的藻类为主导的类群. 在乌伦古湖, 绿球藻目的微 小四角藻和小球藻已成为全年可见的优势类群, 其与鲢、鳙放养的关系如何, 则有待进一步深人研究.

乌伦古湖藻类种类及数量的差异还可能与不同工作者采样点的设置、采样次数、采样时间、采样方

(1) 由于 1978 年, 1985 年的调查中仅对夏季浮游植物数量进行报道, 而 2001-2002 年的调查中仅对浮游植物生物量进行报道, 故本文在对比历史资料分析时采用两个指标. 
法、计数方法及种类鉴定技术和准确程度等诸多因素有关. 从夏季群落结构调查看, 1978年8月和2007年7 月均采样1次，但在1978年8月，只设置了13个采样点，并且仅在湖体表面采集了13个水样，而2007年7月， 设置了 20 个混合采样点和 8 个分层采样点, 共采集 46 个水样 ${ }^{\circledR}$. 从周年群落结构调查看, 2001-2002年和 2006-2007年均是每季度采样1次, 但在2001-2002年, 只设置了13个分层采样点. 本次调查藻类种类及数 量的增长可能与采样点和采样层数的增加有关.

\section{4 参考文献}

[1] 汪宪柜, 王洪道, 张开翔等. 新疆乌伦古湖的自然条件及其渔业生物学基础的初步研究. 海洋湖沼通报, 1981, 4: 18-28.

[2] 中国科学院新疆资源开发综合考察队. 新疆水生生物与渔业. 北京: 科学出版社, 1989.

[3] 叶尚明, 苏德学, 刘＼cjkstart栓等. 新疆乌伦古湖水生生物资源调查研究. 水利渔业, 2006, 24(2): 51-53.

[4] 黄祥飞. 湖泊生态调查观测与分析. 北京: 中国标准出版社, 1999.

[5] 胡鸿钧, 魏印心. 中国淡水藻类——系统、分类及生态. 北京: 科学出版社, 2006.

[6] 黎尚豪, 毕列爵. 中国淡水藻志. 北京: 科学出版社, 1998.

[7] 周凤霞, 陈剑红. 淡水微型生物图谱. 北京: 化学工业出版社, 2005.

[8] Peerapornpisal Y. Freshwater algae in Northern Thailand. Bangkok: The Biodiversity Research and Training Program, 2005.

[9] 南 云, 保·出井雅彦·长田敬五. 硅藻的世界. 东京: 国立科学博物馆, 2003.

[10] 郭玉洁, 钱树本. 中国海澡志. 北京: 科学出版社, 2003.

[11] Baker P, Part I. Identification of common noxious cyanobacteria. Melbourne: Metropolitan Board Press, 1991: 29-43.

[12] 罗民波, 陆健健, 王云龙. 东海浮游植物数量分布与优势种. 生态学报, 2007, 27(12): 5076-5085.

[13] 蒋庆丰, 沈 吉, 刘兴起等. 乌伦古湖介形组合及其壳体同位素记录的全新世气候环境变化. 第四纪研究, 2007, 27(3): 382-391.

[14] Stüken A, Rücker J, Endrulat T et al. Distribution of three alien cyanobacterial species (Nostocales) in northeast Germany: Cylindrospermopsis raciborskii, Anabaena bergii and Aphanizomenon aphanizomenoides. Phycologia, 2006, 45(6): 696-703.

[15] 李立人, 王雪冬. 乌伦古湖水质现状及污染防治对策. 干旱环境监测, 2003, 17(2): 102-105, 116.

[16] 杨清良. 台湾海峡西侧浮游硅藻类的种类组成与分布. 海洋学报, 1995, 17(2): 99-107.

[17] Kirst GO. Salinity tolerance of eukaryotic marine algae. Annual Review of Plant Physiology and Plant Molecular Biology, 1990, 41: 21-53.

[18] Kadiri MO. A spectrum of phytoplankton flora along salinity gradient in the eastern Niger Delta area of Nigeria. Acta Botanica Hungarica, 2002, 44: 75-83.

[19] 高亚辉, 虞秋波, 齐雨藻等. 长江口附近海域春季浮游硅藻的种类组成和生态分布. 应用生态学报, 2003, 14(7): 1044-1048.

[20] 刘 玉, 李适宇, 董燕红等. 珠江口浮游藻类生态及与关键水质因子分析. 海洋环境科学, 2002, 21(3): 61-66.

[21] Davis CC. Evideuce for the eutrophication of Lake Erie from phytoplankton records. Limnol \& Oceanogr, 2003, 9: 275.

[22] 饶钦止, 章宗涉. 武汉东湖浮游植物的演变(1956-1975 年)和富营养化问题. 水生生物学集刊, 1980, 7(1): 1-17.

[23] Korneva LG, Mineeva NM. Phytoplankton composition and pigment concentrations as indicators of water quality in the Rybinsk reservoir. Hydrobiologia, 1996, 322: 255-259.

[24] Reynolds CS. What factors influence the species composition of phytoplankton in lakes of different trophic status? Hydrobiologia, 1998, 369/370: 11-26.

[25] Reynolds CS. Phytoplankton periodicity: The interactions of form, function and environmental variability. Freshwater Biology, 1984, 14: 111-142.

[26] 况琪军, 胡征宇, 周广杰等. 香溪河流域浮游植物调查与水质评价. 武汉植物学研究, 2004, 22(6): 507-513.

[27] 沈暳芬, 章宗涉, 龚循矩. 微型生物监测新技术. 北京：中国建筑工业出版社, 1990.

[28] 况琪军, 马沛明, 胡征宇等. 湖泊富营养化的藻类生物学评价与治理研究进展. 安全与环境学报, 2005, 5(2): 87-91.

(1) 由于 1985 年 8 月的调查未介绍采样点的设置, 故未进行比较. 
[29] 雷安平, 施之新, 魏印心. 武汉东湖浮游藻类物种多样性的研究. 水生生物学报, 2003, 27(2): 179-184.

[30] 刘建康. 东湖生态学研究(二). 北京: 科学出版社, 1995.

[31] 李新贤, 党新成, 李 红等. 新疆主要湖泊、水库的水质综合特征评价模式及营养状态分析. 干旱区地理, 2005, 28(5): 588-591.

[32] 董 做, 江 敏, 刘其根等. 乌伦古湖水质及营养水平调查. 上海水产大学学报, 2008, 17(5): 564-569.

[33] Xie P, Liu J. Practical success of biomanipulation using filter-feeding fish to control cyanobacteria blooms-a synthesis of decades of research and application in a subtropical hypereutrophic lake. The Scientific World, 2001, (1): 337-356.

[34] 刘建康, 谢 平. 用鲢鯶直接控制微囊澡水华的围隔试验和湖泊实践. 生态科学, 2003, 22(3): 193-198.

[35] Jeppesen E, Sndergaard M, Sortkjar O et al. Interactions between phytoplankton, zooplankton and fish in a shallow, hypertrophic lake: A study of phytoplankton collapses in Lake Sbygard, Denmark. Hydrobiologia, 1990, 191: 149-164. 